GRASAS Y ACEITES 72 (3)

July-September 2021, e417

ISSN-L: 0017-3495

https://doi.org/10.3989/gya.0336201

\title{
Improving biodiesel yield from pre-esterified inedible olive oil using microwave-assisted transesterification method
}

\author{
$\oplus$ L. Dehghan ${ }^{\mathrm{a}}, \oplus$ M.-T. Golmakani ${ }^{\mathrm{a}, \bowtie}$ and $\oplus$ S.M.H. Hosseini ${ }^{\mathrm{a}}$

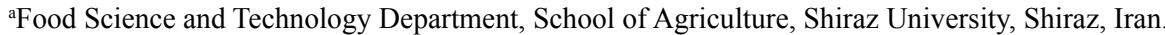 \\ ${ }^{\bowtie}$ Corresponding author: golmakani@shirazu.ac.ir
}

Submitted: 30 March 2020; Accepted: 08 June 2020; Published online: 14 September 2021

SUMMARY: In the present research, biodiesel production from olive oils with different initial free fatty acid concentrations $(2.5,5.0$, and $10.0 \%$ ) was evaluated. A two-stage acid-catalyzed esterification and alkaline-catalyzed transesterification (ACT) process using the microwave heating method was compared with the traditional heating method. Free fatty acid was reduced to less than $2.0 \%$ in the first stage. Although no significant difference was observed between microwave and traditional esterification methods in terms of fatty acid reduction, the microwave treatment significantly decreased reaction time by $92.5 \%$. Comparing microwave ACT results with those of the traditional heating method showed that the microwave can significantly increase methyl ester yield and purity, and simultaneously decrease reaction time. Physical constants of methyl esters were also improved using the microwave heating method. Therefore, the microwave heating method can be regarded as an efficient method instead of the two-stage method for biodiesel production. This method is capable of using inedible olive oil with high concentrations of free fatty acids.

KEYWORDS: Biodiesel; Esterification; Microwave; Olive oil; Transesterification

RESUMEN: Mejora del rendimiento del biodiesel a partir de aceite de oliva no comestible pre-esterificado mediante transesterificación asistida por microondas. En la presente investigación, se evaluó la producción de biodiesel a partir de aceites de oliva con diferentes concentraciones iniciales de ácidos grasos libres (2,5, 5,0 y 10,0\%). Se comparó un proceso de esterificación en dos etapas catalizada con ácido y transesterificación catalizada alcalina (ACT) usando microondas con el método de calentamiento tradicional. Los ácidos grasos libres se redujeron a menos del $2,0 \%$ en la primera etapa. Aunque no se observaron diferencias significativas entre los métodos de esterificación, por microondas y tradicional, en términos de reducción de ácidos grasos, sin embargo, el microondas disminuyó significativamente el tiempo de reacción en un $92,5 \%$. La comparación de los resultados de ACT de microondas con los del método de calentamiento tradicional mostró que el microondas puede aumentar significativamente el rendimiento y la pureza del éster metílico, y simultáneamente disminuir el tiempo de reacción. Las constantes físicas de los ésteres metílicos también se mejoraron usando el método de calentamiento por microondas. Por lo tanto, el método de calentamiento por microondas puede considerarse como un método eficiente en lugar de la producción de biodiésel en dos etapas. Este método es capaz de usar aceite de oliva no comestible con altas concentraciones de ácidos grasos libres.

PALABRAS CLAVE: Aceite de oliva; Biodiesel; Esterificación; Microonda; Transesterificación

Citation/Cómo citar este artículo: Dehghan L, Golmakani M-T, Hosseini SMH. 2021. Improving biodiesel yield from pre-esterified inedible olive oil using microwave-assisted transesterification method. Grasas Aceites 72 (3), e417. https://doi.org/10.3989/gya.0336201

Copyright: $\mathbb{C} 2021$ CSIC. This is an open-access article distributed under the terms of the Creative Commons Attribution 4.0 International (CC BY 4.0) License. 


\section{INTRODUCTION}

Biodiesel or fatty acid alkyl ester is produced via transesterification, which is the reaction of triacylglycerol with an alcohol using an appropriate catalyst. Normally, transesterification is an alkalinecatalyzed reaction which is 4000 times faster than an acid-catalyzed reaction (Fukuda et al., 2001). The cost of biodiesel production is one of the main constituents which can be decreased by choosing waste oils as the source of feedstock (Jaliliannosrati et al., 2013). Meher et al. (2006) investigated the alkaline-catalyzed transesterification of karanja (Pongamia pinnata) oil. They showed that biodiesel yield decreased from 96 to $6.1 \%$ by increasing the free fatty acid (FFA) concentration from 0.48 to $5.75 \%$. Therefore, in order to complete the alkalinecatalyzed reaction, a FFA value of lower than 3\% is needed. The high amounts of FFAs in biodiesel feedstocks make them unsuitable for alkalinecatalyzed transesterification due to the soap formation between FFAs and the alkaline catalyst (Vicente et al., 2004). Soap decreases the reaction yield and acts as a surfactant between the two final immiscible products (methyl ester and glycerol), making downstream separation more difficult and leading to an increase in biodiesel viscosity and purification costs (Mazubert et al., 2014; Sarantopoulos et al., 2014). A similar explanation has been reported in the study by Thoai et al. (2017) on the transesterification of refined palm oil. They showed that by increasing soap concentration from 1.48 to $3.21 \%$, biodiesel purity decreased from 98 to $85 \%$. In addition to soap, water is also another product of saponification. When water is present in the reaction, it generally manifests itself through excessive soap production. Park et al. (2016) investigated the transesterification of wet coffee grounds. They noted that by increasing water from 20 to $80 \%$, biodiesel yield decreased from about 98 to less than $40 \%$. Also, soaps of saturated fatty acids tend to solidify at ambient temperatures. Consequently, a reaction mixture with excessive soap may gel and form a semi-solid mass which is very difficult to recover (Van Gerpen et al., 2004).

Olive oil (OO) has been playing an important role in the world market of vegetable oils. The annual worldwide production of virgin $\mathrm{OO}$ was $3,050,390$ tonnes in 2014, with Spain as its main producer ( $57 \%$ of the global production; $1,738,600$ tonnes/year) (FAOSTAT, 2014). In fact, in Spain, edible vegetable oil consumption is approximately 600,000 tonnes/year. Most of this oil (70\%) is OO and is primarily used for deep frying. According to the INE (Spanish National Institute of Statistics), about 74,000 tonnes of waste OO is collected per year. In this sense, the transesterification of waste OO for producing biodiesel could decrease the waste disposal problem. Although several approaches have been developed to produce biodiesel from vegetable oils and animal fats, research concerning biodiesel production from waste $\mathrm{OO}$ is limited and further research is needed. Due to the presence of moisture and hydrolytic enzymes, the FFA concentration in the waste OO rises rapidly (Shahidi, 2005). Dorado et al. (2003) and Yuste and Dorado (2006) investigated the transesterification of waste $\mathrm{OO}$ for biodiesel production using a conventional heating method. Waste $\mathrm{OO}$ with high FFA is inedible and its refining is costly. Therefore, this high free fatty acid olive oil (HFFAOO) is economically suitable for biodiesel production. Due to undesirable outcomes, HFFAOO needs to be pre-treated before transesterification. Kara et al. (2017) applied an acid-catalyzed esterification pre-treatment for reducing high FFA concentrations in waste fish oil from 28 to less than $1.5 \%$. The pre-treated oil is then transformed using alkaline-catalyzed transesterification (Sarantopoulos et al., 2014).

Several heating methods have been investigated for biodiesel production. In conventional heating methods, heat energy is transferred to the raw material by convection and conduction from the hot surface of the reactor, which requires a long time and large amounts of energy (Talebian-Kiakalaieh et al., 2013). Microwave radiation is a novel heating method which can be used for a large number of chemical reactions such as esterification and transesterification (Talebian-Kiakalaieh et al., 2013). Generally, two mechanisms of dipolar rotation and ionic conduction have been introduced for the interaction between microwave energy and raw materials. Polar materials such as methanol can absorb microwave radiation and the ionic molecules, such as $\mathrm{KOH}$, can be divided into positive and negative ions. At the same time, the probability of molecular encounters increases by accelerating the molecular/ionic movement which leads to an increased reaction rate (Sajjadi et al., 2014). Lin and Chen (2017) transesterified Jatropha oil and showed that for obtaining biodiesel purity 
higher than $90 \%$, microwave requires just 10 seconds while the conventional hot plate requires 1 hour. Also, energy consumptions of conventional hot plate and microwave heating methods were 2376 and $9.5 \mathrm{~kJ}$, respectively.

Even though some studies have proposed a twostep reaction of acid-catalyzed esterification followed by alkaline-catalyzed transesterification for biodiesel production, none of them is based on comparison between different heating methods in both steps. Therefore, the aim of the present study was to use a microwave heating method for esterification of $\mathrm{OO}$ with different initial FFA concentrations followed by its transesterification and to compare it with the conventional magnetic stirrer method. Purity, yield, physical properties, and composition of the fatty acid methyl esters (FAMEs) produced were also compared.

\section{MATERIALS AND METHODS}

\subsection{Materials}

All experimental chemicals (solvents, reagents, and standards) were of analytical grade and were purchased from Merck (Darmstadt, Germany) and Sigma-Aldrich (St. Louis, MO). Crude OO mill (three-phase centrifuge) was supplied from Etka Oil Company (Rudbar, Iran).

\subsection{Methods}

\subsubsection{Acid-catalyzed esterification}

Microwave-assisted esterification (MAE) was carried out with sulfuric acid (10\%, w/w H2SO4/ FFA) as catalyst. The catalyst was dissolved in methanol (methanol to FFA mole ratio of 40) and was stirred for $5 \mathrm{~min}$ to ensure complete mixing. According to the American Oil Chemists' Society (AOCS) Official Method (Ca 5a-40), FFA of OO was $2.36 \%$ which increased to $2.5,5.0$, and $10.0 \%$ by pure oleic acid (AOCS, 2000). The catalystmethanol solution was mixed with $100 \mathrm{~g}$ high FFA OO. The reaction was carried out for $9 \mathrm{~min}$ in a domestic microwave oven (ME3410W, Samsung Malaysia Electronics, Kuala Lumpur, Malaysia) at $500 \mathrm{~W}$ with a wave frequency of $2450 \mathrm{MHz}$, equipped with a condenser (to condense back the methanol escaping from the reaction mixture). Also, the magnetic stirrer operated at $60{ }^{\circ} \mathrm{C}$ for $120 \mathrm{~min}$ at $600 \mathrm{rpm}$ as a conventional-assisted esterification
(CAE). At the end of the reaction time, the reaction mixture was immediately cooled down to room temperature. The water-soluble components were separated from the product in a separatory funnel. The esterification yield was calculated according to the following equation (Chai et al., 2014):

Esterification yield $(\%)=(($ initial FFA - final FFA $) /$ initial FFA) $\times 100$ eq. (1)

\subsubsection{Alkaline-catalyzed transesterification}

$\mathrm{KOH}$ was dissolved in methanol and the mixture was stirred for $10 \mathrm{~min}$ to ensure complete mixing. Then, the catalyst-methanol solution was mixed with $100 \mathrm{~g}$ esterified HFFAOO. The reaction was carried out using the microwave oven and the conventional magnetic stirrer.

Microwave-assisted transesterification (MAT) of esterified HFFAOO was carried out at $500 \mathrm{~W}$, methanol-to-oil mole ratio of $9, \mathrm{KOH}$ concentration of $1.2 \%$, and reaction time of $9 \mathrm{~min}$. Conventionalassisted transesterification (CAT) was performed using a magnetic stirrer at $60{ }^{\circ} \mathrm{C}$ for $120 \mathrm{~min}$ at $600 \mathrm{rpm}$. To evaluate the effect of esterification pre-treatment on transesterification yield, OO samples (with 2.5, 5.0, and 10.0\% FFA) were also transesterified without esterification pre-treatment.

At the end of the reaction time, the reaction mixture was immediately cooled down to room temperature and transferred to a separating funnel where it was left overnight to separate into two phases. The crude methyl ester remained in the upper phase, while the catalyst and unreacted methanol were situated in the lower glycerol phase, meaning that small amounts of catalyst, methanol, and glycerol were present in the upper phase. The excess methanol in the ester phase was distilled off with a magnetic stirrer equipped with a condenser at $70{ }^{\circ} \mathrm{C}$ for $30 \mathrm{~min}$ at $450 \mathrm{rpm}$. Hot distilled water $\left(60{ }^{\circ} \mathrm{C}\right)$ was sprayed over the surface of ester phase to remove the impurities and catalyst. Washing was performed 5 times to remove all dissolved catalysts and glycerol in the ester phase. The lower phase was discarded and a yellow-colored phase containing FAMEs was finally isolated. FAMEs were then dried using a magnetic stirrer at $80{ }^{\circ} \mathrm{C}$ for $30 \mathrm{~min}$ at $250 \mathrm{rpm}$ (Kanitkar et al., 2011; Patil et al., 2011). Margaric acid methyl ester (Methyl margarate; Methyl heptadecanoate) was added to the crude 


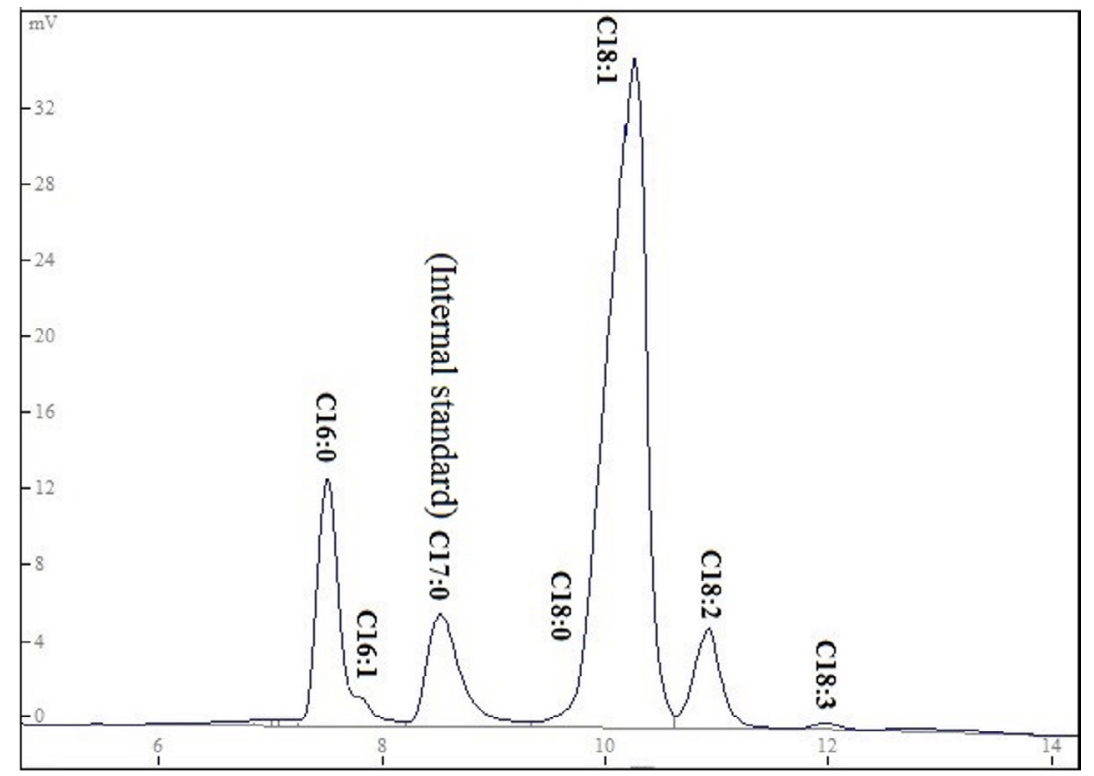

FIGURE 1. Chromatogram of microwave-assisted transesterified inedible olive oil.

FAMEs as an internal standard (Figure 1) (Atapour and Kariminia, 2011). The purity of FAMEs was determined using the GC/FID method according to the method described by Golmakani et al., (2012a; $2012 \mathrm{~b}$ ). The weight of yield, methyl ester purity, and final yield were calculated according to the following equations (Patil et al., 2011; Hsiao et al., 2010):

Weight of yield $(\%)=(($ Weight of final product $(\mathrm{g})) /($ Weight of olive oil (g) ) $) \times 100$

Methyl ester purity $(\%)=(($ Area of final product $) /$ (Area of internal standard $) \times(($ Weight of internal standard(g) $) /$ (Weight of final product $(\mathrm{g}))) \times 100$ eq. (3) Final yield $(\%)=(($ Methyl ester purity $(\%) \times$ Weight of yield $(\%)) / 100)$

\subsubsection{Physical properties of FAME}

Kinematic viscosity, refractive index, and density of purified FAMEs were analyzed according to the method of the American Society for Testing Materials (ASTM; D445), AOCS Cc7-25 Official Method, and AOCS 1a-64 Official Method, respectively (AOCS, 2000; ASTM, 2013). The fatty acid composition of FAMEs was determined according to the method described by Golmakani et al., (2012a; 2012b). Color attributes (L*, lightness; $a^{*}$, greenness to redness; $b^{*}$, blueness to yellowness) of FAMEs were analyzed using the Habibi et al. (2016) method.

\subsubsection{Statistical analysis}

All experiments were performed in triplicate and the data were reported as mean values of the measurements. Standard deviation values are presented in all tables. A general linear model (GLM) procedure from SAS (Statistical Analysis Software, version 9.1; SAS Institute Inc. Cary, NC) was used for comparison of mean values.

\section{RESULTS}

\subsection{Esterification yield}

The effects of initial FFA concentration and esterification method on the esterification yield of HFFAOO are shown in Table 1. The highest esterification yield was obtained for $2.5 \%$ initial FFA (i.e. final FFA of lower than $0.5 \%$ ). Although there were no significant differences between the esterification yield of HFFAOO with 5.0\% FFA and that of $10.0 \%$, their esterification yields were lower than that of the sample with $2.5 \%$ FFA. Also, despite the fact that there were no significant differences between MAE and CAE methods in terms of final FFA concentration and esterification yield, MAE entailed significantly lower esterification duration and energy consumption. Microwaves heat methanol selectively which may lead to the rapid formation of microzones (hot spots) with temperatures much higher than that of 
Improving biodiesel yield from pre-esterified inedible olive oil using microwave-assisted transesterification method $\bullet$

TABLE 1. Effect of microwave heating method on esterification yield of high free fatty acid olive oil

\begin{tabular}{cccc}
\hline $\begin{array}{c}\text { Initial free fatty acid } \\
\text { concentration }\end{array}$ & Esterification method & $\begin{array}{c}\text { Final free fatty acid } \\
\text { concentration }\end{array}$ & Esterification yield (\%) \\
\hline 2.5 & Conventional & $0.47 \pm 0.02 \mathrm{c}$ & $81.44 \pm 0.79 \mathrm{a}$ \\
2.5 & Microwave & $0.45 \pm 0.01 \mathrm{c}$ & $82.00 \pm 0.36 \mathrm{a}$ \\
5 & Conventional & $1.01 \pm 0.01 \mathrm{~b}$ & $80.10 \pm 0.03 \mathrm{~b}$ \\
5 & Microwave & $1.01 \pm 0.01 \mathrm{~b}$ & $80.08 \pm 0.06 \mathrm{~b}$ \\
10 & Conventional & $2.06 \pm 0.08 \mathrm{a}$ & $79.48 \pm 0.50 \mathrm{~b}$ \\
10 & Microwave & $1.98 \pm 0.04 \mathrm{a}$ & $80.27 \pm 0.38 \mathrm{~b}$ \\
\hline
\end{tabular}

* Mean \pm standard deviation; Number of replicates for each analysis: 3; Statistical test: ANOVA and multiple comparison of means using Duncan's test; Degree of significance: $\mathrm{P}<0.05$; In each column, means with different letters are significantly different.

TABLE 2. Effect of different esterification and transesterification methods on weight of yield, purity, and final yield of olive oil biodiesel

\begin{tabular}{cccccc}
\hline $\begin{array}{c}\text { Initial free fatty } \\
\text { acid concentration }\end{array}$ & $\begin{array}{c}\text { Esterification } \\
\text { method }\end{array}$ & $\begin{array}{c}\text { Transesterification } \\
\text { method }\end{array}$ & $\begin{array}{c}\text { Weight of yield } \\
\mathbf{( \% )}\end{array}$ & Purity (\%) & Final yield (\%) \\
\hline 2.5 & WEP* & Conventional & $82.36 \pm 0.03 \mathrm{~m}^{* *}$ & $96.03 \pm 0.03 \mathrm{~d}$ & $79.09 \pm 0.06 \mathrm{i}$ \\
2.5 & WEP & Microwave & $85.72 \pm 0.011$ & $97.86 \pm 0.18 \mathrm{c}$ & $83.88 \pm 0.17 \mathrm{f}$ \\
2.5 & Conventional & Conventional & $93.15 \pm 0.01 \mathrm{~g}$ & $89.33 \pm 0.76 \mathrm{e}$ & $83.21 \pm 0.71 \mathrm{~g}$ \\
2.5 & Conventional & Microwave & $98.57 \pm 0.05 \mathrm{~b}$ & $99.94 \pm 0.03 \mathrm{a}$ & $98.50 \pm 0.08 \mathrm{a}$ \\
2.5 & Microwave & Conventional & $93.36 \pm 0.01 \mathrm{f}$ & $89.77 \pm 0.25 \mathrm{e}$ & $83.81 \pm 0.22 \mathrm{fg}$ \\
2.5 & Microwave & Microwave & $98.98 \pm 0.03 \mathrm{a}$ & $99.94 \pm 0.03 \mathrm{a}$ & $98.93 \pm 0.00 \mathrm{a}$ \\
5 & WEP & Conventional & $68.32 \pm 0.03 \mathrm{o}$ & $2.92 \pm 0.07 \mathrm{i}$ & $2.00 \pm 0.05 \mathrm{k}$ \\
5 & WEP & Microwave & $76.72 \pm 0.01 \mathrm{n}$ & $3.18 \pm 0.08 \mathrm{i}$ & $2.44 \pm 0.06 \mathrm{k}$ \\
5 & Conventional & Conventional & $92.08 \pm 0.04 \mathrm{i}$ & $87.90 \pm 1.08 \mathrm{fg}$ & $80.94 \pm 0.96 \mathrm{~h}$ \\
5 & Conventional & Microwave & $96.51 \pm 0.01 \mathrm{~d}$ & $99.82 \pm 0.03 \mathrm{a}$ & $96.33 \pm 0.03 \mathrm{c}$ \\
5 & Microwave & Conventional & $92.27 \pm 0.03 \mathrm{~h}$ & $88.24 \pm 0.24 \mathrm{f}$ & $81.42 \pm 0.24 \mathrm{~h}$ \\
5 & Microwave & Microwave & $97.60 \pm 0.02 \mathrm{c}$ & $99.90 \pm 0.01 \mathrm{a}$ & $97.50 \pm 0.03 \mathrm{~b}$ \\
10 & WEP & Conventional & $44.06 \pm 0.01 \mathrm{q}$ & $0.65 \pm 0.02 \mathrm{j}$ & $0.28 \pm 0.011$ \\
10 & WEP & Microwave & $52.33 \pm 0.01 \mathrm{p}$ & $0.68 \pm 0.02 \mathrm{j}$ & $0.36 \pm 0.011$ \\
10 & Conventional & Conventional & $89.08 \pm 0.05 \mathrm{k}$ & $87.07 \pm 0.05 \mathrm{~h}$ & $77.55 \pm 0.00 \mathrm{j}$ \\
10 & Conventional & Microwave & $95.37 \pm 0.01 \mathrm{e}$ & $98.62 \pm 0.13 \mathrm{~b}$ & $94.05 \pm 0.14 \mathrm{e}$ \\
10 & Microwave & Conventional & $90.13 \pm 0.03 \mathrm{j}$ & $87.24 \pm 0.13 \mathrm{hg}$ & $78.63 \pm 0.15 \mathrm{i}$ \\
10 & Microwave & Microwave & $96.46 \pm 0.04 \mathrm{~d}$ & $98.90 \pm 0.01 \mathrm{~b}$ & $95.40 \pm 0.05 \mathrm{~d}$ \\
\hline
\end{tabular}

* WEP: Without Esterification pre-treatment; ** Mean \pm standard deviation; Number of replicates for each analysis: 3; Statistical test: ANOVA and multiple comparison of means using Duncan's test; Degree of significance: $\mathrm{P}<0.05$; In each column, means with different letters are significantly different.

the reaction mixture, thus providing enough energy for increasing the esterification rate (Sajjadi et al., 2014). Unlike microwave, the conventional heating method heats the entire reaction mixture (both methanol and OO), leading to longer reaction time and higher energy consumption (Kumar et al., 2011). These findings are in good agreement with the results of Suppalakpanya et al. (2010), who produced ethyl ester from crude palm oil. They showed that MAE and CAE methods reduced FFA concentration from 7.5 to less than $2 \%$ after reaction times of 60 and $240 \mathrm{~min}$, respectively.

\subsection{Transesterification yield}

The effects of different initial FFA concentrations and transesterification methods on weight of yield, purity, and final yield of HFFAOO are shown in 
Table 2. The weight of yield, purity, and final yield of transesterified HFFAOOs without esterification were significantly lower than those of esterified ones. The final yield of HFFAOOs with 2.5, 5.0, and 10.0\% FFA were $81.48,2.22$, and $0.32 \%$, respectively. There were no significant differences between the final yield of $\mathrm{OO}$ with 5.0 and $10.0 \%$ FFA. In view of the fact that high initial FFA concentration increases the saponification reaction, esterification pre-treatment plays a key role in increasing transesterification purity and yield. MAT significantly increased the final yield of OO with $2.5 \%$ FFA in comparison with that from the CAT method.

In the case of esterified samples (both CAT and MAT methods), the weight of yield, purity, and final yield of FAMEs decreased by increasing the initial FFA concentration. Higher initial FFA concentration leads to increasing soap formation, which resulted in decreasing biodiesel purity and yield.

The highest final yield was obtained using the microwave heating method both in the esterification and transesterification steps. Also, the lowest final yield was obtained using the conventional heating method in both the esterification and transesterification steps. MAT showed higher weight of yield, purity, and final yield in comparison with the CAT method. Microwave radiation can selectively heat polar molecules (alcohols) without significantly heating non-polar molecules (triacylglycerols), which promotes transesterification rate and hence improves the yield and purity of FAMEs. In the conventional heating method, energy is transferred to the reaction mixture through convention and conduction only, which requires a long time and large amounts of energy (Wahidin et al., 2014). Similar to our results, Wahidin et al. (2014) investigated the effects of MAT on the biodiesel yield of microalgal Nannochloropsis oculata oil. They reported that the final yield of MAT (86.41\%) was higher than that of the conventional water bath method (71.26\%).

\subsection{FAME analysis}

\subsubsection{Fatty acid composition}

The effect of different esterification and transesterification methods on the fatty acid composition of the biodiesel produced are shown in Table 3. There were no significant differences among the fatty acid compositions of different initial FFA concentrations or different esterification and transesterification methods.
Therefore, transesterification rate is not dependent on the chain length or saturation degree of fatty acids. This phenomenon can be related to the speed and completeness of the transesterification reaction. In contrast to our finding, Stavarache et al. (2007) noted that saturated fatty acids, which are commonly located in the 1 and 3 positions of triacylglycerols, had a higher transesterification rate.

\subsubsection{Physical properties of transesterified samples}

The effect of different esterification and transesterification methods on the physical properties of the biodiesel produced are shown in Table 4. The kinematic viscosity of FAME is one of the most important properties which can affect storage condition, transportation, and biodiesel operation. HFFAOO samples transesterified without esterification had higher kinematic viscosity than those of esterified samples (both CAT and MAT methods). The kinematic viscosity of unesterified samples with 5.0 and $10.0 \%$ FFA after transesterification was similar to untreated OO (i.e. without esterification and transesterification; 36.806 $\mathrm{mm}^{2} / \mathrm{s}$ ). This phenomenon can be related to the fact that although most triacylglycerols participated in the saponification reaction instead of transesterification, transesterification was not affected by saponification in the case of $\mathrm{OO}$ with $2.5 \%$ FFA. Also, in spite of the fact that the transesterification method had no significant effect on kinematic viscosity, the MAT of $\mathrm{OO}$ with $2.5 \%$ FFA had significantly higher kinematic viscosity than the CAT method.

According to ASTM D6751 Official Methods, the kinematic viscosity of FAMEs should be 1.9-6 $\mathrm{mm}^{2} / \mathrm{s}$. Except for the FAMEs of OO with 5.0 and $10.0 \%$ FFA transesterified without esterification, all the FAMEs fall within the standard range indicated by ASTM.

In the case of esterified samples, MAT samples had lower kinematic viscosity than those of the CAT method. By increasing the initial FFA concentration from 2.5 to $10.0 \%$, the kinematic viscosity of FAMEs increased due to soap formation. There was a significant negative correlation between kinematic viscosity and final yield $\left(\mathrm{R}^{2}=0.972\right.$; kinematic viscosity $=(-0.065 \times$ Final yield $)+$ 10.413). During the transesterification process, triacylglycerols are converted to lower molecular weight FAMEs (Talebian-Kiakalaieh et al., 2013). 
Improving biodiesel yield from pre-esterified inedible olive oil using microwave-assisted transesterification method $\bullet$

TABLE 3. Effect of different esterification and transesterification methods on fatty acid composition of olive oil biodiesel

\begin{tabular}{|c|c|c|c|c|c|c|c|c|}
\hline \multirow{2}{*}{$\begin{array}{c}\text { Initial free } \\
\text { fatty acid } \\
\text { concentration } \\
(\%)\end{array}$} & \multirow[b]{2}{*}{$\begin{array}{l}\text { Esterification } \\
\text { method }\end{array}$} & \multirow[b]{2}{*}{$\begin{array}{c}\text { Transesterification } \\
\text { method }\end{array}$} & \multicolumn{6}{|c|}{ Fatty acid (\%) } \\
\hline & & & Palmitic acid & $\begin{array}{l}\text { Palmitoleic } \\
\text { acid }\end{array}$ & $\begin{array}{l}\text { Stearic } \\
\text { acid }\end{array}$ & Oleic acid & $\begin{array}{l}\text { Linoleic } \\
\text { acid }\end{array}$ & $\begin{array}{l}\alpha \text {-Linolenic } \\
\text { acid }\end{array}$ \\
\hline 2.5 & WEP* & Conventional & $15.53 \pm 0.05 * *$ & $1.30 \pm 0.05$ & $2.19 \pm 0.85$ & $71.78 \pm 0.85$ & $8.95 \pm 0.00$ & $0.25 \pm 0.01$ \\
\hline 2.5 & WEP & Microwave & $15.97 \pm 0.07$ & $1.36 \pm 0.08$ & $1.92 \pm 0.48$ & $71.55 \pm 0.48$ & $8.95 \pm 0.00$ & $0.25 \pm 0.05$ \\
\hline 2.5 & Conventional & Conventional & $14.54 \pm 0.00$ & $1.37 \pm 0.00$ & $1.94 \pm 0.00$ & $72.03 \pm 0.00$ & $9.65 \pm 0.00$ & $0.47 \pm 0.00$ \\
\hline 2.5 & Conventional & Microwave & $15.50 \pm 0.09$ & $1.36 \pm 0.08$ & $1.42 \pm 0.11$ & $72.17 \pm 0.12$ & $9.08 \pm 0.00$ & $0.47 \pm 0.02$ \\
\hline 2.5 & Microwave & Conventional & $14.65 \pm 0.03$ & $1.26 \pm 0.03$ & $1.94 \pm 0.00$ & $72.03 \pm 0.00$ & $9.65 \pm 0.00$ & $0.47 \pm 0.00$ \\
\hline 2.5 & Microwave & Microwave & $15.60 \pm 1.02$ & $1.36 \pm 0.16$ & $2.40 \pm 0.18$ & $71.56 \pm 0.96$ & $8.63 \pm 0.63$ & $0.45 \pm 0.03$ \\
\hline 5 & WEP & Conventional & $15.15 \pm 0.79$ & $1.50 \pm 0.00$ & $2.50 \pm 0.00$ & $71.10 \pm 0.04$ & $9.35 \pm 3.83$ & $0.40 \pm 0.00$ \\
\hline 5 & WEP & Microwave & $15.13 \pm 0.76$ & $1.50 \pm 0.00$ & $2.50 \pm 0.00$ & $72.33 \pm 0.61$ & $8.24 \pm 8.37$ & $0.30 \pm 0.07$ \\
\hline 5 & Conventional & Conventional & $15.64 \pm 0.07$ & $1.17 \pm 0.07$ & $1.86 \pm 0.16$ & $72.30 \pm 0.16$ & $8.71 \pm 0.00$ & $0.32 \pm 0.03$ \\
\hline 5 & Conventional & Microwave & $15.54 \pm 0.04$ & $1.32 \pm 0.04$ & $1.35 \pm 0.22$ & $72.24 \pm 0.22$ & $9.08 \pm 0.00$ & $0.47 \pm 0.00$ \\
\hline 5 & Microwave & Conventional & $15.55 \pm 0.03$ & $1.26 \pm 0.03$ & $1.48 \pm 0.38$ & $72.68 \pm 0.38$ & $8.71 \pm 0.00$ & $0.32 \pm 0.03$ \\
\hline 5 & Microwave & Microwave & $15.41 \pm 0.12$ & $1.43 \pm 0.15$ & $2.82 \pm 0.73$ & $71.06 \pm 0.33$ & $8.89 \pm 0.26$ & $0.39 \pm 0.11$ \\
\hline 10 & WEP & Conventional & $15.37 \pm 0.36$ & $1.50 \pm 0.00$ & $1.95 \pm 0.00$ & $71.56 \pm 1.54$ & $9.32 \pm 2.90$ & $0.30 \pm 0.04$ \\
\hline 10 & WEP & Microwave & $15.22 \pm 4.82$ & $1.20 \pm 0.00$ & $2.00 \pm 0.00$ & $71.97 \pm 1.50$ & $9.21 \pm 5.31$ & $0.40 \pm 0.02$ \\
\hline 10 & Conventional & Conventional & $14.65 \pm 0.01$ & $1.26 \pm 0.01$ & $1.30 \pm 0.46$ & $72.70 \pm 0.45$ & $9.62 \pm 0.00$ & $0.47 \pm 0.08$ \\
\hline 10 & Conventional & Microwave & $15.54 \pm 0.04$ & $1.32 \pm 0.04$ & $1.35 \pm 0.22$ & $72.24 \pm 0.22$ & $9.08 \pm 0.00$ & $0.47 \pm 0.00$ \\
\hline 10 & Microwave & Conventional & $15.58 \pm 0.01$ & $1.44 \pm 0.01$ & $2.27 \pm 0.92$ & $71.05 \pm 0.92$ & $9.37 \pm 0.00$ & $0.29 \pm 0.03$ \\
\hline 10 & Microwave & Microwave & $15.42 \pm 0.08$ & $1.44 \pm 0.08$ & $2.02 \pm 0.40$ & $71.58 \pm 0.40$ & $9.07 \pm 0.00$ & $0.47 \pm 0.06$ \\
\hline
\end{tabular}

* WEP: Without esterification pre-treatment; ** Mean \pm standard deviation; Number of replicates for each analysis: 3.

TABLE 4. Effect of different esterification and transesterification methods on physical properties of olive oil biodiesel

\begin{tabular}{|c|c|c|c|c|c|c|c|c|}
\hline \multirow{2}{*}{$\begin{array}{l}\text { Initial free fatty acid } \\
\text { concentration }(\%)\end{array}$} & \multirow{2}{*}{$\begin{array}{c}\text { Esterification } \\
\text { method }\end{array}$} & \multirow{2}{*}{$\begin{array}{l}\text { Transesterification } \\
\text { method }\end{array}$} & \multirow{2}{*}{$\begin{array}{l}\text { kinematic viscosity } \\
(\mathrm{mm} 2 / \mathrm{s})\end{array}$} & \multirow{2}{*}{ Density (Kg/m3) } & \multirow{2}{*}{ Refractive index } & \multicolumn{3}{|c|}{ Color attribute } \\
\hline & & & & & & $L^{*}$ & $\mathrm{a}^{*}$ & $b^{*}$ \\
\hline 2.5 & WEP** & Conventional & $5.194 \pm 0.000 c^{* * *}$ & $881.1685 \pm 0.0637 \mathrm{~g}$ & $1.4544 \pm 0.0001 \mathrm{~d}$ & $58.50 \pm 0.35 \mathrm{~d}$ & $-8.25 \pm 0.35 \mathrm{~cd}$ & $44.50 \pm 0.71 \mathrm{c}$ \\
\hline 2.5 & WEP & Microwave & $4.159 \pm 0.000 \mathrm{f}$ & $885.1601 \pm 0.0920 \mathrm{~d}$ & $1.4531 \pm 0.0001 \mathrm{de}$ & $60.75 \pm 0.35 \mathrm{ab}$ & $-8.60 \pm 0.14 \mathrm{~cd}$ & $39.00 \pm 0.00 \mathrm{de}$ \\
\hline 2.5 & Conventional & Conventional & $5.126 \pm 0.000 \mathrm{~d}$ & $881.9488 \pm 0.0495 f$ & $1.4544 \pm 0.0001 \mathrm{~d}$ & $59.25 \pm 0.35 \mathrm{~cd}$ & $-8.60 \pm 0.14 c d$ & $43.50 \pm 0.71 \mathrm{c}$ \\
\hline 2.5 & Conventional & Microwave & $4.019 \pm 0.001 \mathrm{hi}$ & $886.9658 \pm 0.0424 \mathrm{a}$ & $1.4526 \pm 0.0001 \mathrm{fg}$ & $61.50 \pm 0.71 \mathrm{a}$ & $-9.25 \pm 0.35 \mathrm{e}$ & $36.50 \pm 0.71 \mathrm{f}$ \\
\hline 2.5 & Microwave & Conventional & $5.018 \pm 0.001 \mathrm{e}$ & $883.1693 \pm 0.0637 \mathrm{e}$ & $1.4544 \pm 0.0001 \mathrm{~d}$ & $58.50 \pm 0.71 \mathrm{~d}$ & $-8.75 \pm 0.07 \mathrm{de}$ & $42.90 \pm 0.14 \mathrm{c}$ \\
\hline 2.5 & Microwave & Microwave & $4.016 \pm 0.001 \mathrm{i}$ & $886.9658 \pm 0.2404 \mathrm{a}$ & $1.4524 \pm 0.0001 \mathrm{~g}$ & $61.50 \pm 0.71 \mathrm{a}$ & $-9.25 \pm 0.35 \mathrm{e}$ & $36.50 \pm 0.71 \mathrm{f}$ \\
\hline 5 & WEP & Conventional & $36.752 \pm 0.033 b$ & $874.5209 \pm 0.0141 \mathrm{~h}$ & $1.4629 \pm 0.0001 \mathrm{~b}$ & $56.50 \pm 0.71 \mathrm{e}$ & $-6.65 \pm 0.21 \mathrm{~b}$ & $54.50 \pm 0.71 \mathrm{~b}$ \\
\hline 5 & WEP & Microwave & $36.760 \pm 0.001 \mathrm{~b}$ & $874.8761 \pm 0.0212 \mathrm{~h}$ & $1.4627 \pm 0.0000 \mathrm{~b}$ & $56.55 \pm 0.07 \mathrm{e}$ & $-6.75 \pm 0.07 b$ & $54.10 \pm 0.14 \mathrm{~b}$ \\
\hline 5 & Conventional & Conventional & $5.127 \pm 0.000 \mathrm{~d}$ & $881.9288 \pm 0.1344 \mathrm{~g}$ & $1.4545 \pm 0.0001 \mathrm{~d}$ & $59.24 \pm 0.34 \mathrm{~cd}$ & $-8.60 \pm 0.14 \mathrm{~cd}$ & $43.50 \pm 0.71 \mathrm{c}$ \\
\hline 5 & Conventional & Microwave & $4.035 \pm 0.001 \mathrm{~h}$ & $887.0408 \pm 0.0212 \mathrm{a}$ & $1.4525 \pm 0.0002 \mathrm{~g}$ & $61.50 \pm 0.71 \mathrm{a}$ & $-9.25 \pm 0.35 \mathrm{e}$ & $36.50 \pm 0.71 \mathrm{f}$ \\
\hline 5 & Microwave & Conventional & $5.118 \pm 0.000 \mathrm{~d}$ & $881.9338 \pm 0.1132 \mathrm{f}$ & $1.4545 \pm 0.0003 \mathrm{~d}$ & $59.25 \pm 0.35 \mathrm{~cd}$ & $-8.60 \pm 0.14 \mathrm{~cd}$ & $43.50 \pm 0.71 \mathrm{c}$ \\
\hline 5 & Microwave & Microwave & $4.018 \pm 0.000 \mathrm{j}$ & $887.0008 \pm 0.0071 \mathrm{a}$ & $1.4526 \pm 0.0001 \mathrm{fg}$ & $61.50 \pm 0.71 \mathrm{a}$ & $-9.25 \pm 0.35 \mathrm{e}$ & $36.50 \pm 0.71 \mathrm{f}$ \\
\hline 10 & WEP & Conventional & $36.798 \pm 0.000 \mathrm{a}$ & $874.1603 \pm 0.0134 \mathrm{i}$ & $1.4692 \pm 0.0001 \mathrm{a}$ & $56.49 \pm 0.01 \mathrm{e}$ & $-5.25 \pm 0.35 \mathrm{a}$ & $56.25 \pm 0.35 \mathrm{a}$ \\
\hline 10 & WEP & Microwave & $36.798 \pm 0.000 \mathrm{a}$ & $874.1898 \pm 0.0014 \mathrm{i}$ & $1.4691 \pm 0.0001 \mathrm{a}$ & $56.51 \pm 0.01 \mathrm{e}$ & $-5.40 \pm 0.14 \mathrm{a}$ & $55.75 \pm 0.35 \mathrm{a}$ \\
\hline 10 & Conventional & Conventional & $5.207 \pm 0.001 \mathrm{c}$ & $881.1685 \pm 0.0637 \mathrm{~g}$ & $1.4552 \pm 0.0002 \mathrm{c}$ & $58.50 \pm 0.71 \mathrm{~d}$ & $-8.10 \pm 0.14 c$ & $44.50 \pm 0.71 \mathrm{c}$ \\
\hline 10 & Conventional & Microwave & $4.106 \pm 0.000 \mathrm{~g}$ & $885.8954 \pm 0.3537 \mathrm{c}$ & $1.4529 \pm 0.0001 \mathrm{fe}$ & $61.05 \pm 0.07 \mathrm{ab}$ & $-8.75 \pm 0.35 \mathrm{de}$ & $37.90 \pm 0.14 \mathrm{e}$ \\
\hline 10 & Microwave & Conventional & $5.194 \pm 0.000 \mathrm{c}$ & $881.1885 \pm 0.0637 \mathrm{~g}$ & $1.4553 \pm 0.0004 \mathrm{c}$ & $58.50 \pm 0.71 \mathrm{~d}$ & $-8.10 \pm 0.14 c$ & $44.50 \pm 0.71 \mathrm{c}$ \\
\hline 10 & Microwave & Microwave & $4.104 \pm 0.000 \mathrm{~g}$ & $886.240 \pm 0.0071 \mathrm{~b}$ & $1.4529 \pm 0.0001 \mathrm{fe}$ & $61.10 \pm 0.14 \mathrm{ab}$ & $-8.75 \pm 0.35 \mathrm{de}$ & $37.90 \pm 0.14 \mathrm{e}$ \\
\hline
\end{tabular}

** WEP: Without esterification pre-treatment; *** Mean \pm standard deviation; Number of replicates for each analysis: 3 ; Statistical test: ANOVA and multiple comparison of means using Duncan's test; Degree of significance: $\mathrm{P}<0.05$; In each column, means with different letters are significantly different. 
Hence, by increasing the biodiesel final yield, kinematic viscosity decreased accordingly. The sample with the highest final yield $(98.93 \%)$ showed the lowest kinematic viscosity $\left(4.02 \mathrm{~mm}^{2} / \mathrm{s}\right)$. In both esterification and transesterification steps, the microwave heating method was more effective than the conventional heating method due to its higher yield of FAME production and accordingly lower kinematic viscosity.

For both CAT and MAT methods, HFFAOO samples transesterified without esterification had lower density in comparison with esterified samples. In the case of unesterified samples, although the transesterification method of OO with 5.0 and $10.0 \%$ FFA had no significant effect on density, microwaveassisted transesterified $\mathrm{OO}$ with $2.5 \%$ FFA had significantly higher density than the CAT method.

In the case of transesterified samples, the MAT of OO showed higher density than that of the CAT method. By increasing the initial FFA concentration, the densities of FAMEs were decreased. There was a significant positive correlation between density and final yield $\left(\mathrm{R}^{2}=0.98\right.$; Density $=(0.299 \times$ Final yield $)+857.720$ ). The lower molecular weight of FAMEs in comparison with their corresponding triacylglycerols plays a key role in determining the density of the product (Motasemi and Ani, 2012). Therefore, by increasing final yield (i.e. higher production of lower molecular weight FAMEs), the density of the produced biodiesel increased. Using MAT led to higher final yield and hence density.

The refractive indices of HFFAOO samples transesterified without esterification were higher than those of esterified samples using both CAE and MAE methods. Also, different transesterification methods had no significant effect on refractive indices of $\mathrm{OO}$ with $2.5,5.0$, or $10.0 \%$ FFA.

In the case of esterified HFFAOOs, microwaveassisted transesterified samples had lower refractive indices. By increasing initial FFA concentration, the refractive indices of FAMEs increased. There was a significant negative correlation between refractive index and final yield $\left(\mathrm{R}^{2}=0.982\right.$; Refractive index $=$ $(-0.0001 \times$ Final yield $)+1.465)$. By increasing final yield, refractive index decreased due to the conversion of triacylglycerols to lower molecular weight FAMEs. Also, microwave-assisted transesterified samples showed lower refractive indices according to their higher final yield.
Color is a qualitative parameter for evaluating the effects of the transesterification process on the biodiesel produced. HFFAOO samples transesterified without esterification had lower L*, $a^{*}$, and $b^{*}$ values than those of esterified samples using either conventional or microwave methods. Regarding unesterified samples, although different transesterification methods of $\mathrm{OO}$ with 5.0 and $10.0 \%$ FFA had no significant effect on $\mathrm{L}^{*}, \mathrm{a}^{*}$, and $b^{*}$ values, microwave-assisted transesterified $\mathrm{OO}$ with $2.5 \%$ FFA had significantly higher $L^{*}$ value and lower $b^{*}$ value than those of the CAT method. Also, the $\mathrm{a}^{*}$ value for OO with $2.5 \%$ FFA was similar in both MAT and CAT methods.

In the case of esterified samples, microwaveassisted transesterified samples had higher $\mathrm{L}^{*}$ values and lower $\mathrm{a}^{*}$ and $\mathrm{b}^{*}$ values than those of conventionalassisted transesterified samples. Although there were no significant differences among different initial FFA concentrations in terms of $\mathrm{L}^{*}$ and $\mathrm{a}^{*}$ values, microwave-assisted transesterified OO with $10.0 \%$ FFA had significantly higher $b^{*}$ values than those of OO with 2.5 and $5.0 \%$ FFA. There was a positive correlation between the $\mathrm{L}^{*}$ value and final yield $\left(\mathrm{R}^{2}\right.$ $=0.948 ; \mathrm{L}^{*}$ value $=(0.152 \times$ Final yield $\left.)+46.597\right)$. Also, there was a negative correlation between the $\mathrm{a}^{*}$ value and final yield $\left(R^{2}=0.803 ; a^{*}\right.$ value $=(-0.044$ $\times$ Final yield) -4.889$)$ and between the $b^{*}$ value and final yield $\left(R^{2}=0.985 ; b *\right.$ value $=(-0.4175 \times$ Final yield) +77.45$)$. Therefore, although the $L^{*}$ value increased by increasing final yield, both $\mathrm{a}^{*}$ and $\mathrm{b}^{*}$ values decreased. The microwave heating method showed the highest $\mathrm{L}^{*}$ value $(61.50)$ and at the same time the lowest $a^{*}$ and $b^{*}$ values $(9.25$ and 36.50 , respectively).

The physical properties of the FAMEs produced are meaningfully related to their transesterification final yield. Therefore, the physical properties of FAMEs can be used as reliable indices for predicting transesterification yield.

\section{CONCLUSIONS}

In this study, the effects of the microwave heating method on the esterification and transesterification of HFFAOO were evaluated in comparison with the conventional heating method. By increasing the initial FFA concentration, the weight of yield, purity, and final yield of FAMEs decreased significantly. Although there were no significant differences between the 
yields of MAE and CAE, the MAE reaction time was significantly lower than CAE. Also, MAT significantly increased FAME yield and simultaneously decreased reaction time in comparison with the CAT method. Therefore, the microwave heating method can be introduced as a suitable alternative method for twostep biodiesel production from different vegetable oils (olive, palm, canola, soybean, safflower, sunflower, etc.). Although the number of studies on the feasibility of novel technologies (such as reactive distillation, membrane reactor, oscillatory baffled reactor, ohmic, ultrasound, etc.) for biodiesel production is significant, detailed analyses of two-step biodiesel production from high free fatty acid waste oils using novel technologies are still needed.

\section{ACKNOWLEDGMENTS}

This research project was financially supported by Shiraz University. We would like to thank the Edible Oil Industry Group of Etka Organization for providing the OO. We also thank Seyed Ali Hosseini for editing the English language version of the paper.

\section{REFERENCES}

AOCS. 2000. Official Methods and Recommended Practices of the American Oil Chemists' Society (5th ed.). USA, AOCS Press, Champaign, Illinois ASTM. 2013. Standard Specification for Biodiesel Fuel Blend Stock (B100) for Distillate Fuels, ASTM D6751-12

Atapour M, Kariminia HR. 2011. Characterization and transesterification of Iranian bitter almond oil for biodiesel production. Appl. Energy 88, 2377-2381. https://doi.org/10.1016/j.apenergy.2011.01.014

Chai M, Tu Q, Lu M, Yang YJ. 2014. Esterification pretreatment of free fatty acid in biodiesel production, from laboratory to industry. Fuel Process Technol. 125, 106-113. https://doi. org/10.1016/j.fuproc.2014.03.025

Dorado MP, Ballesteros E, Arnal JM, Gómez J, López FJ. 2003. Exhaust emissions from a Diesel engine fueled with transesterified waste olive oil. Fuel 82, 1311-1315. https://doi.org/10.1016/ S0016-2361(03)00034-6

FAOSTAT. 2014. www. fao.org/faostat

Fukuda H, Kondo A, Noda H. 2001. Biodiesel fuel production by transesterification of oils. J. Biosci. Bioeng. 92, 405-416. https://doi.org/10.1016/ S1389-1723(01)80288-7
Golmakani M-T, Mendiola JA, Rezaei K, Ibanez E. 2012a. Expanded ethanol with $\mathrm{CO}_{2}$ and pressurized ethyl lactate to obtain fractions enriched in $\gamma$-Linolenic Acid from Arthrospira platensis (Spirulina). J. Supercrit. Fluid 62, 109 115. https://doi.org/10.1016/j.supflu.2011.11.026 Golmakani M-T, Rezaei K, Mazidi S, Razavi SH. 2012b. Effect of alternative $\mathrm{C} 2$ carbon sources on the growth, lipid, and $\gamma$-linolenic acid production of Spirulina (Arthrospira platensis). Food Sci. Biotechnol. 21, 355-363. https://doi.org/10.1007/ s10068-012-0047-8

Habibi M, Golmakani M-T, Farahnaky A, Mesbahi G, Majzoobi M. 2016. NaOH-free debittering of table olives using power ultrasound. Food Chem. 192, 775-781. https://doi.org/10.1016/j. foodchem.2015.07.086

Hsiao MC, Lin CC, Chang YH, Chen LC. 2010. Ultrasonic mixing and closed microwave irradiation-assisted transesterification of soybean oil. Fuel 89, 3618-3622. https://doi.org/10.1016/j. fuel.2010.07.044

Jaliliannosrati H, Amin NAS, Talebian-Kiakalaieh A, Noshadi I. 2013. Microwave assisted biodiesel production from Jatropha curcas L. seed by twostep in situ process: Optimization using response surface methodology. Bioresour. Technol. 136, 565573. https://doi.org/10.1016/j.biortech.2013.02.078 Kanitkar A, Balasubramanian S, Lima M, Boldor D. 2011. A critical comparison of methyl and ethyl esters production from soybean and rice bran oil in the presence of microwaves. Bioresour. Technol. 102, 7896-7902. https://doi.org/10.1016/j. biortech.2011.05.091

Kara K, Ouanji F, Lotfi EM, Mahi ME, Kacimi M, Ziyad M. 2018. Biodiesel production from waste fish oil with high free fatty acid content from Moroccan fish-processing industries. Egypt J. Pet. 27, 249255. https://doi.org/10.1016/j.ejpe.2017.07.010

Kumar R, Kumar GR, Chandrashekar N. 2011. Microwave assisted alkali-catalyzed transesterification of Pongamia pinnata seed oil for biodiesel production. Bioresour. Technol. 102, 6617-6620. https://doi.org/10.1016/j. biortech.2011.03.024

Lin J, Chen Y. 2017. Production of biodiesel by transesterification of Jatropha oil with microwave heating. J. Taiwan Inst. Chem. E. 75, 43-50. https://doi.org/10.1016/j.jtice.2017.03.034 
Mazubert A, Taylor C, Aubin J, Poux M. 2014. Key role of temperature monitoring in interpretation of microwave effect on transesterification and esterification reactions for biodiesel production. Bioresour. Technol. 161, 270-279. https://doi. org/10.1016/j.biortech.2014.03.011

Meher LC, Kulkarni MG, Dalai AK, Na S. 2006. Transesterification of karanja (Pongamia pinnata) oil by solid basic catalysts. Eur. J. Lipid Sci. Tech. 108, 389-397. https://doi.org/10.1002/ ejlt.200500307

Motasemi F, Ani FN. 2012. A review on microwaveassisted production of biodiesel. Renew. Sust. Energ. Rev. 16, 4719-4733. https://doi. org/10.1016/j.rser.2012.03.069

Park J, Kim B, Lee JW. 2016. In-situ transesterification of wet spent coffee grounds for sustainable biodiesel production. Bioresour. Technol. 221, 5560. https://doi.org/10.1016/j.biortech.2016.09.001

Patil P, Gude VG, Pinappu S, Deng S. 2011. Transesterification kinetics of Camelina sativa oil on metal oxide catalysts under conventional and microwave heating conditions. Chem. Eng. J. 168, 1296-1300. https://doi.org/10.1016/j. cej.2011.02.030

Sajjadi B,Abdul AzizAR, Ibrahim S. 2014. Investigation, modelling and reviewing the effective parameters in microwave-assisted transesterification. Renew. Sust. Energ. Rev. 37, 762-777. https://doi.org/10.1016/j. rser.2014.05.021

Sarantopoulos I, Chatzisymeon E, Foteinis S, Tsoutsos T. 2014. Optimization of biodiesel production from waste lard by a two-step transesterification process under mild conditions. Energy Sustain. Dev. 23, 110-114. https://doi.org/10.1016/j.esd.2014.08.005

Shahidi F. 2005. Bailey's Industrial Oil and Fat Products (6th ed.). New Jersey, USA, John Wiley and Sons Inc.Publication.
Stavarache C, Vinatoru M, Nishimura R, Maeda Y. 2007. Aspects of ultrasonically assisted transesterification of various vegetable oils with methanol. Ultrason. Sonochem. 14, 380-386. https://doi.org/10.1016/j.ultsonch.2006.08.004

Suppalakpanya K, Ratanawilai S, Tongurai C. 2010. Production of ethyl ester from crude palm oil by two-step reaction with a microwave system. Fuel 89, 2140-2144. https://doi.org/10.1016/j. fuel.2010.04.003

Talebian-Kiakalaieh A, Amin NAS, Mazaheri H. 2013. A review on novel processes of biodiesel production from waste cooking oil. Appl. Energy 104, 683-710. https://doi.org/10.1016/j.apenergy.2012.11.061

Thoai DN, Tongurai C, Prasertsit K, Kumar A. 2017. A novel two-step transesterification process catalyzed by homogeneous base catalyst in the first step and heterogeneous acid catalyst in the second step. Fuel Process Technol. 168, 97-104. https://doi.org/10.1016/j.fuproc.2017.08.014

Van Gerpen J, Shanks B, Pruszko R, Clements D, Knothe G. 2004. Biodiesel Production Technology. National Renewable Energy Laboratory. www.nrel. gov

Vicente G, Martinez M, Aracil J. 2004. Integrated biodiesel production: a comparison of different homogeneous catalysts systems. Bioresour. Technol. 92, 297-305. https://doi.org/10.1016/j. biortech.2003.08.014

Wahidin S, Idris A, Muhamad Shaleh SR. 2014. Rapid biodiesel production using wet microalgae via microwave Irradiation. Energ. Convers. Manage. 84, 227-233. https://doi.org/10.1016/j. enconman.2014.04.034

Yuste AJ, Dorado MP.2006. A neural network approach to simulate biodiesel production from waste olive oil. Energ. Fuel. 20, 399-402. https:// doi.org/10.1021/ef050226t 